\title{
Target tissues for relaxin identified in vitro with ${ }^{125}$ I-labelled porcine relaxin
}

\author{
J. P. McMurtry*, S. C. M. Kwok† and Gillian D. Bryant-Greenwood \\ Department of Anatomy and Reproductive Biology, University of Hawaii, \\ Honolulu, Hawaii 96822 , U.S.A.
}

\begin{abstract}
Summary. Various tissues from the mouse, rat and guinea-pig were used to examine the binding of a biologically active, esterified and ${ }^{125} \mathrm{I}$-labelled porcine relaxin. Binding to mouse symphysial homogenates was time- and temperature-dependent. Other peptide hormones did not compete with relaxin for binding. Mouse uterine tissue displayed similar binding characteristics. Fractionated mammary tissue from 15and 20-day-pregnant rats exhibited significant relaxin binding activity, as did homogenates of the guinea-pig pubic symphysis and cervix. Under the conditions used, no relaxin receptors were noted in the liver, spleen or heart from any of the species investigated.
\end{abstract}

\section{Introduction}

The polypeptide hormones which have been shown to bind to various target tissue preparations are insulin (Cuatrecasas, 1971), ACTH (Lefkowitz, Roth, Pricer \& Pastan, 1970), gonadotrophins (Catt, Dufau \& Tsuruhara, 1972; Kammerman, Canfield, Kolera \& Channing, 1972), epidermal growth factor (O'Keefe, Hollenberg \& Cuatrecasas, 1974) and prolactin (Shiu, Kelly \& Friesen, 1973). The characterization of specific binding sites has been demonstrated by showing that an iodinated and biologically-active hormone which is bound to a tissue preparation can be displaced by physiological amounts of the native hormone but not by unrelated hormones. Relaxin is an ovarian peptide hormone which acts on target tissues such as the interpubic ligament of the oestrogen-primed mouse (Steinetz et al., 1960), the oestrogen-primed rat uterus (Wiquist \& Paul, 1958) and the pregnant rat mammary gland (Harness \& Anderson, 1975). The present study of the sites of action of relaxin in these tissues is a detailed survey involving the use of a highly purified porcine relaxin.

\section{Materials and Methods}

Hormones. Relaxin was purified from fresh frozen pregnant sow ovaries (Farmer John \& Co., Los Angeles, California, U.S.A.) by the method of Sherwood \& O'Byrne (1974). The resulting preparation yielded three relaxins, CM-B, CM-a and CM-a': CM-a' was used throughout this study and will be referred to as relaxin. Porcine insulin and porcine glucagon (No. 258-D30-138-4) were generously provided by Eli Lilly Pharmaceutical Co., Indianapolis, U.S.A. Human FSH (LER No. 907) was kindly provided by the National Pituitary Agency. Epidermal growth factor (EGF) was prepared by the method of Savage \& Cohen (1972) and was a gift from Mr J. Baker, Department of Biochemistry, University of Hawaii. U.S.A.

+ Present address: Department of Biochemistry and Biophysics, University of Hawaii, Honolulu, Hawaii 96822 , U.S.A. 
Bioassay of relaxin and succinylated relaxin. The mouse interpubic ligament bioassay (Steinetz et al., 1960) was used for the potency determinations of the purified relaxin preparation and of succinylated relaxin. CM-B, CM-a, and $\mathrm{CM}-\mathrm{a}^{\prime}$ were respectively $3.65,4.85$, and 3.97 times more potent than the NIH-R-P1 preparation (442 guinea-pig units/mg). Succinylation was carried out as described below for the iodination of relaxin except that the succinylated relaxin was not exposed to $\mathrm{Na}^{125} \mathrm{I}$, chloramine $\mathrm{T}$, and sodium metabisulphite. The results of the assays were evaluated for parallelism by statistical methods as described by Bliss (1952).

Iodination. Because porcine relaxin contains no tyrosine (Sherwood \& O'Byrne, 1974), the iodination method of Bolton \& Hunter (1973) was used with the following modifications. Crystalline $\mathrm{N}$-hydroxy-succinimide ester $(1 \mu \mathrm{g})$ (Fluka Chemical Co., Buchs, Switzerland) was dissolved in $20 \mu \mathrm{l}$ redistilled benzene and dried under vacuum. To this was added $25 \mu \mathrm{g}$ relaxin dissolved in $20 \mu \mathrm{l}$ $0 \cdot 1 \mathrm{~m}$-sodium borate buffer, $\mathrm{pH} 8.5$. After mixing for $15 \mathrm{~min}$ at $0^{\circ} \mathrm{C} 1-2 \mathrm{mCi} \mathrm{Na}^{125}$ (AmershamSearle, Chicago, Illinois, U.S.A.) were added, followed immediately by $100 \mu \mathrm{l}$ chloramine $\mathrm{T}$ dissolved in $20 \mu \mathrm{l} 0.25 \mu$-sodium phosphate buffer, $\mathrm{pH} 7 \cdot 5$. After reaction for $15-20 \mathrm{sec}, 240 \mu \mathrm{g}$ sodium metabisulphite $(20 \mu \mathrm{l}$ in $0.05 \mathrm{M}$-sodium phosphate buffer, $\mathrm{pH} 7.5)$ and $100 \mu \mathrm{g}$ potassium iodide solution in $0.05 \mathrm{M}$-sodium phosphate buffer, $\mathrm{pH} 7.5$, were added. ${ }^{125}$ I-labelled succinylated relaxin was separated from unreacted succinimide ester and from free ${ }^{125} \mathrm{I}$ by passage through a $2 \mathrm{~g}$ Sephadex G-25 column which was presaturated with $0.05 \%$ gelatin in $0.05 \mathrm{M}$-sodium phosphate buffer, $\mathrm{pH} 7.5$. Highly purified relaxin was labelled with ${ }^{125}$ I to specific activities of $45-60 \mu \mathrm{Ci} / \mu \mathrm{g}$ by using the above procedure. Iodination damage, as determined by paper chromato-electrophoresis (Berson, Yalow, Baumann, Rothschild \& Newerly, 1956), was mostly $<15 \%$.

\section{Tissue homogenates}

Mouse pubic symphysis. Immature female mice (18-20 g) were treated subcutaneously with $5 \mu \mathrm{g}$ oestradiol cyclopentylpropionate (K \& K Chemicals, Plainview, New York, U.S.A.) as described by Steinetz et al. (1960). On Day 7 the pubic symphyses were removed, dissected free of fascia and pooled. To facilitate homogenization the tissue was incubated in $1 \%$ collagenase (Sigma Chemical Co., St Louis, Missouri, U.S.A.) for $30 \mathrm{~min}$ at $37^{\circ} \mathrm{C}$, followed by two rinsings with $\mathbf{0 \cdot 3}$ $\mathrm{M}$-sucrose. Homogenization in a glass homogenizer was carried out in $0.3 \mathrm{M}$-sucrose at a $1: 4(\mathrm{w} / \mathrm{v})$ ratio. The homogenate was centrifuged at $2000 \mathrm{~g}$, the supernatant was decanted and the precipitate was resuspended in an equal volume of Tris- $\mathrm{MgSO}_{4}$ buffer ( $25 \mathrm{~mm}-\mathrm{Tris}-\mathrm{HCl}, 5 \mathrm{~mm}-\mathrm{MgSO}_{4}$ ), $\mathrm{pH} \mathrm{7.5}$. Control tissues (heart, spleen and liver) were handled similarly except that the incubation step with collagenase was omitted.

Rat mammary gland. Mammary tissue was removed from pregnant rats at 5, 10,15 or 20 days post coitum or from lactating rats at Days 5 and 10 after parturition, rinsed and homogenized $(1: 10 \mathrm{w} / \mathrm{v})$ in ice-cold $0.3 \mathrm{M}$-sucrose. The homogenate was filtered through cheesecloth and centrifuged at $1500 \mathrm{~g}$ for $20 \mathrm{~min}$. The supernatant was centrifuged at $15000 \mathrm{~g}$ for $20 \mathrm{~min}$ and then at $100000 \mathrm{~g}$ for $90 \mathrm{~min}$ in an L3-40 ultracentrifuge. The resulting precipitate was resuspended in an equal volume of Tris- $\mathrm{MgSO}_{4}$ buffer ( $\left.25 \mathrm{~mm}-\mathrm{Tris}-\mathrm{HCl}, 5 \mathrm{~mm}-\mathrm{MgSO}_{4}\right) \mathrm{pH} \mathrm{7 \cdot 5}$. Heart, spleen and liver homogenates were fractionated in the same fashion.

Aliquots of the mammary gland $100000 \mathrm{~g}$ fraction and of the interpubic ligament homogenate were solubilized with $1 \mathrm{~N}-\mathrm{NaOH}$ and the protein concentration was determined by the method of Lowry, Rosebrough, Farr \& Randall (1951) by using bovine serum albumin as standard. The tissue preparations were stored at $4^{\circ} \mathrm{C}$ until assayed approximately $12 \mathrm{~h}$ later.

\section{Binding studies}

Tissue homogenates. ${ }^{125} \mathrm{I}$-labelled relaxin $(1 \mathrm{ng} / \mathrm{ml})$ was incubated with either $100 \mu$ interpubic ligament homogenate $(2.5 \mathrm{mg}$ protein) or $100 \mu \mathrm{l}$ of the mammary gland $100000 \mathrm{~g}$ fraction $(485 \mu \mathrm{g}$ protein) and $400 \mu \mathrm{g} \mathrm{BSA}$ in Tris- $\mathrm{MgSO}_{4}$ buffer ( $25 \mathrm{~mm}$-Tris- $\mathrm{HCl}, 5 \mathrm{~mm}-\mathrm{MgSO}_{4}$ ), pH 7.5, made up to a total volume of $400 \mu \mathrm{l}$. The assays were conducted in duplicate or triplicate at 4,22 or $37^{\circ} \mathrm{C}$. Simultaneous incubations were run in the presence of excess unlabelled relaxin $(5 \mu \mathrm{g})$ to determine non-specific binding. Bound and free ${ }^{125} \mathrm{I}$-labelled hormone were separated by centrifugation at 
$1000 \mathrm{~g}$ for $15 \mathrm{~min}$. The specific binding of ${ }^{125} \mathrm{I}$-labelled relaxin was obtained by subtracting from total binding the amount of labelled hormone bound in the presence of high concentrations of unlabelled hormone.

Uterine segments. These were obtained from the oestrogen-primed mice from which the pubic symphyses were removed or from mature rats which had been given an injection of $5 \mu \mathrm{g}$ oestradiol cyclopentylpropionate $24 \mathrm{~h}$ earlier. For the studies of relaxin uptake, three $5 \mathrm{mg}$ segments were placed in each $25 \mathrm{ml}$ flask containing Krebs-Ringer bicarbonate buffer $(0 \cdot 155 \mathrm{M}-\mathrm{NaCl}, 0 \cdot 154 \mathrm{M}-\mathrm{KCl}$, $0.154 \mathrm{M}-\mathrm{KH}_{2} \mathrm{PO}_{4}, 0.154 \mathrm{M}-\mathrm{MgSO}_{4}$ and $1.3 \% \mathrm{NaHCO}_{3}$ ), $\mathrm{pH} 7.5$, with $0.2 \%$ glucose, and gassed with $95 \% \mathrm{O}_{2}+5 \% \mathrm{CO}_{2}$. Labelled relaxin $(1 \mathrm{ng} / \mathrm{ml})$ was added to the flasks and incubated at 4,22 or $37^{\circ} \mathrm{C}$ for 5, 50, 100 and $250 \mathrm{~min}$. Parallel incubations were performed with excess unlabelled relaxin $(12.5 \mu \mathrm{g})$ in the flasks. After incubation the segments were removed, washed twice in cold KrebsRinger bicarbonate, blotted and weighed. Radioactivity uptake was expressed in terms of c.p.m./mg tissue as a percentage of the total radioactivity in the incubation medium. Portions ( $5 \mathrm{mg})$ of heart, liver and spleen were processed similarly.

\section{Results}

The results of the mouse interpubic ligament bioassay of $\mathrm{CM}-\mathrm{a}^{\prime}$ relaxin and succinylated relaxin are shown in Table 1 . At all dosages, treated animals had significantly longer $(P<0 \cdot 01$, Students $t$ test, Steel \& Torrie, 1960) ligaments than did the controls. There was no loss of biological potency when relaxin was succinylated, but it is possible that the activity of the iodinated and succinylated relaxin might have been affected.

Table 1. Estimation of potency of relaxin and succinylated-relaxin by means of the effect on the length $(\mathrm{mm})$ of the pubic ligament of mice (16/group, means \pm s.e.m.)

\begin{tabular}{|c|c|c|}
\hline $\begin{array}{c}\text { Dose } \neq \\
(\mu g)\end{array}$ & Relaxin* & Succinylated relaxin $\dagger$ \\
\hline 0 & $0.34 \pm 0.02$ & $0.34 \pm 0.02$ \\
\hline 0.25 & $1.07 \pm 0.19$ & $1.01 \pm 0.23$ \\
\hline 0.50 & $1.81 \pm 0.41$ & $1.88 \pm 0.58$ \\
\hline 1.00 & $2.63 \pm 0.27$ & $2.79 \pm 0.46$ \\
\hline $\begin{array}{r}* \mathrm{Fr} \\
\text { per } \mathrm{mg} . \\
\dagger \mathrm{Pr} \\
\text { Method } \\
\ddagger \mathrm{Di} \\
\text { diluted }\end{array}$ & $\begin{array}{l}\text { ion CM-a' } \\
\text { ared as deso } \\
\text { lved in } 1 \% \\
\text { desired con }\end{array}$ & $\begin{array}{l}=1755 \text { guinea-pig units } \\
\text { cribed in 'Materials and } \\
\text { benzopurpurin 4-B and } \\
\text { centration. }\end{array}$ \\
\hline
\end{tabular}

Pubic symphysis tissue. The total binding of iodinated porcine relaxin to a mouse pubic symphysial homogenate was dependent on the time and temperature of incubation (Text-fig. 1). At $37^{\circ} \mathrm{C}$, equilibrium was reached within $60 \mathrm{~min}$, and there was no further change of binding during an additional $3 \mathrm{~h}$ incubation. Non-specific binding at each temperature was minimal $(<3 \%)$. There was no binding of iodinated relaxin in the spleen, liver and heart tissue homogenates.

The binding ability of symphysial homogenates from untreated mice and those treated with oestrogen was tested as shown in Table 2. Maximal binding was observed after $60 \mathrm{~min}$ and there was no statistical difference between the homogenates at any of the incubation times tested, or when unlabelled relaxin was added. 


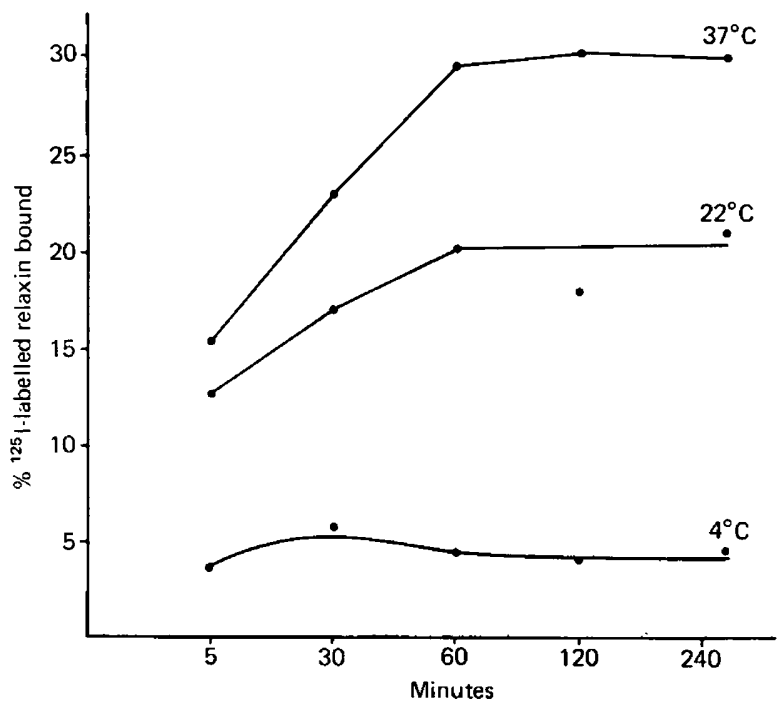

Text-fig. 1. Effect of temperature and incubation time on the specific binding of ${ }^{125}$ I-labelled porcine relaxin to homogenates of mouse pubic symphysis. Each point represents the mean of triplicate determinations.

Table 2. Effect of oestrogen priming on the binding of ${ }^{125} \mathrm{I}$-labelled porcine relaxin to mouse interpubic ligament homogenates

\begin{tabular}{lrrrr}
\hline & \multicolumn{4}{c}{ Time of incubation at $37^{\circ} \mathrm{C}(\mathrm{min})$} \\
\cline { 2 - 5 } & \multicolumn{1}{c}{5} & \multicolumn{1}{c}{30} & 60 & 90 \\
\hline No oestrogen & $15.6 \pm 0.08$ & $25.1 \pm 0.01$ & $30.2 \pm 0.04$ & $30.6 \pm 0.02$ \\
Oestrogen-treated* & $14.9 \pm 0.11$ & $24.8 \pm 0.21$ & $29.7 \pm 0.03$ & $29.9 \pm 0.01$ \\
Excess unlabelled relaxin $(5 \mu \mathrm{g})$ & $7.7 \pm 0.00$ & $10.0 \pm 0.72$ & $9.9 \pm 0.13$ & $9.6 \pm 0.29$ \\
\hline
\end{tabular}

Values represent the mean \pm s.e.m. of triplicate determinations of the $\%$ of labelled relaxin bound.

* See text.

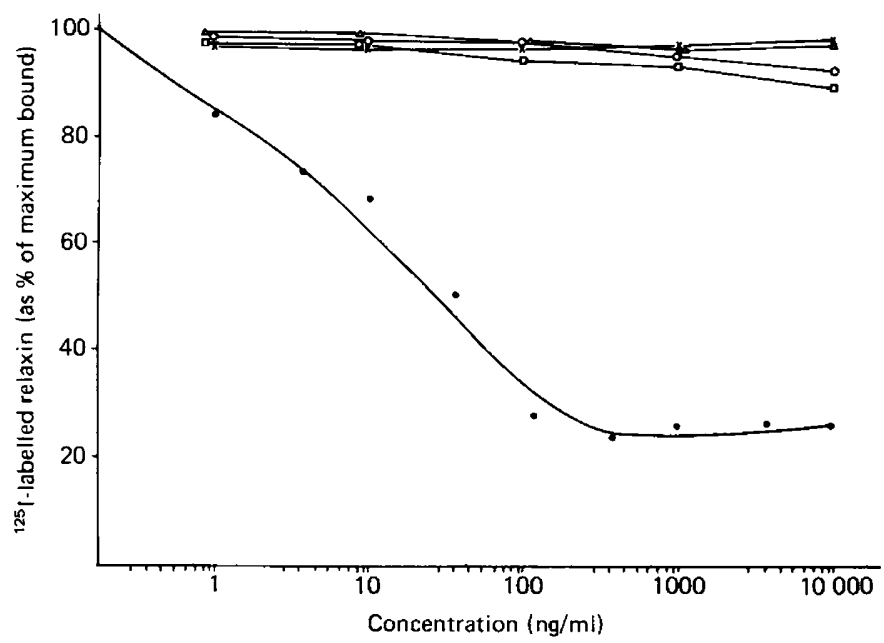

Text-fig. 2. Competition for ${ }^{125} \mathrm{I}$-labelled porcine relaxin to mouse symphysial homogenates by unlabelled porcine relaxin $(\bullet)$, porcine insulin $(O)$, human FSH $(\times)$, porcine glucagon $(\square)$ and epidermal growth factor $(\triangle)$. Each point represents the mean of duplicate determinations. 
In the conditions for maximal binding $\left(60-\mathrm{min}\right.$ incubation at $\left.37^{\circ} \mathrm{C}\right)$ the displacement of labelled relaxin $(1 \mathrm{ng} / \mathrm{ml})$ by unlabelled relaxin was examined in hormone concentrations from 1 to 10000 $\mathrm{ng} / \mathrm{ml}$. Unlabelled relaxin at a level of $1 \mathrm{ng} / \mathrm{ml}$ reduced the specific binding of ${ }^{125} \mathrm{I}$-labelled relaxin by $16 \%$. Porcine insulin and glucagon, human FSH and epidermal growth factor all displayed minimal competition $(<2 \%)$ at all concentrations tested (Text-fig. 2 ).

Uterine tissues. The results of the assays with mouse and rat uterine segments are shown in Table 3. For both species, the binding pattern was similar, being minimal at $4^{\circ} \mathrm{C}$ and maximal at $37^{\circ} \mathrm{C}$. In mouse segments incubated at $37^{\circ} \mathrm{C}$, there was decreased binding at 250 min and this was apparently due to metabolism or degradation of the labelled hormone because the analysis of eluates of incubation media on a G-25 Sephadex column showed that $85 \%$ of the radioactivity was free ${ }^{125} \mathrm{I}$ or fragmented radioiodinated relaxin.

Table 3. Specific binding (expressed as $\%$ of total radioactivity bound, c.p.m./mg tissue) of ${ }^{125}$ I-labelled relaxin to uterine segments of rats and mice primed with oestrogen

\begin{tabular}{lccccc}
\hline & & \multicolumn{5}{c}{ Incubation time (min) } \\
\cline { 3 - 6 } Species & $\begin{array}{l}\text { Incubation } \\
\text { temp. }\left({ }^{\circ} \mathrm{C}\right)\end{array}$ & 5 & 50 & 100 & 250 \\
\hline Rat & 4 & $0.12 \pm 0.01$ & $0.18 \pm 0.00$ & $0.15 \pm 0.03$ & $0.17 \pm 0.01$ \\
Mouse & 22 & $0.31 \pm 0.02$ & $0.62 \pm 0.01$ & $0.70 \pm 0.19$ & $0.73 \pm 0.24$ \\
& 4 & $0.09 \pm 0.00$ & $0.23 \pm 0.09$ & $0.49 \pm 0.04$ & $0.46 \pm 0.02$ \\
& 22 & $0.41 \pm 0.13$ & $0.55 \pm 0.18$ & $1.92 \pm 0.89$ & $1.87 \pm 0.63$ \\
& 37 & $2.00 \pm 0.02$ & $2.77 \pm 0.57$ & $3.85 \pm 0.92$ & $3.45 \pm 0.17$ \\
\hline
\end{tabular}

Values are the mean \pm s.e.m. of duplicate determinations.

Table 4. Specific binding of ${ }^{125} \mathrm{I}$-labelled relaxin and the effect of insulin and epidermal growth factor (EGF) on this binding to rat and mouse uterine segments incubated for $100 \mathrm{~min}$ at $37^{\circ} \mathrm{C}$ in Krebs-Ringer bicarbonate containing $1 \mathrm{ng}$ ${ }^{125} \mathrm{I}$-labelled $\mathrm{relaxin} / \mathrm{ml}$

\begin{tabular}{|c|c|c|c|}
\hline \multirow[b]{2}{*}{ Hormone } & \multirow[b]{2}{*}{$\begin{array}{l}\text { Concentration } \\
(\mathrm{ng} / \mathrm{ml})\end{array}$} & \multicolumn{2}{|c|}{$\%$ Specific binding } \\
\hline & & $\begin{array}{c}\text { Rat } \\
\text { uterus }\end{array}$ & $\begin{array}{l}\text { Mouse } \\
\text { uterus }\end{array}$ \\
\hline \multirow[t]{10}{*}{ Relaxin } & 0 & $100-0$ & $100 \cdot 0$ \\
\hline & 1 & $98 \cdot 5$ & $88 \cdot 4$ \\
\hline & 5 & $94 \cdot 6$ & $70 \cdot 4$ \\
\hline & 10 & $83 \cdot 7$ & $59 \cdot 2$ \\
\hline & 50 & $80 \cdot 1$ & 59.4 \\
\hline & 100 & $60 \cdot 4$ & $50 \cdot 0$ \\
\hline & 500 & $57 \cdot 9$ & $46 \cdot 8$ \\
\hline & 1000 & $39 \cdot 5$ & $39 \cdot 3$ \\
\hline & 5000 & $37 \cdot 3$ & -* \\
\hline & 10000 & $39 \cdot 8$ & 40.6 \\
\hline \multirow[t]{4}{*}{ Insulin } & 1 & 99.6 & 99.4 \\
\hline & 10 & 99.9 & 98.9 \\
\hline & 100 & $99 \cdot 8$ & 99.9 \\
\hline & 1000 & $98 \cdot 7$ & $99 \cdot 7$ \\
\hline \multirow[t]{4}{*}{ EGF } & 1 & $98 \cdot 8$ & $100 \cdot 0$ \\
\hline & 10 & $99 \cdot 7$ & $100 \cdot 0$ \\
\hline & 100 & $100 \cdot 0$ & $98 \cdot 2$ \\
\hline & 1000 & $98 \cdot 5$ & $98 \cdot 8$ \\
\hline
\end{tabular}

Values are the means of duplicate determinations.

* Sample lost. 
The specific binding of ${ }^{125} \mathrm{I}$-labelled relaxin to mouse and rat uterine tissues is shown in Table 4. At low hormone concentrations, unlabelled relaxin was less effective in displacing the radiolabelled hormone in the rat than in the mouse uterine segments. No specific binding was observed in the control tissues examined (spleen, liver and heart), and there was no competition by porcine insulin or epidermal growth factor for binding sites at the hormone concentrations tested (Table 4).

Mammary gland tissues. The incubation results with various tissues are shown in Table 5. Binding was obtained only with the $100000 \mathrm{~g}$ fractions: the $1500 \mathrm{~g}$ and $15000 \mathrm{~g}$ fractions were tested for all the mammary gland preparations but they had no relaxin-binding activity. Relaxin binding sites were undetectable early in pregnancy and lactation (Days 5 and 10; data not shown). The binding was greatest to tissues from late pregnant rats, and was time- and temperature-dependent. Maximal specific binding was attained after incubation for $60 \mathrm{~min}$ at $22^{\circ} \mathrm{C}$. A similar pattern of binding activity was found for homogenates of the pubic symphysis and cervices from 2 guinea pigs (Table $5)$.

Table. 5 Specific binding (as $\%$ of total relaxin bound) of ${ }^{125}$ I-labelled relaxin to mammary gland tissue of pregnant rats and virgin guinea-pig tissues

\begin{tabular}{|c|c|c|c|c|c|}
\hline \multirow[b]{2}{*}{ Tissue } & \multirow[b]{2}{*}{ Temp. $\left({ }^{\circ} \mathrm{C}\right)$} & \multicolumn{4}{|c|}{ Incubation time (min) } \\
\hline & & 15 & 30 & 60 & 120 \\
\hline $\begin{array}{l}\text { *Pregnant rat mammary gland } \\
\text { (Day 15) }\end{array}$ & 22 & $0.21 \pm 0.01$ & $0 \cdot 19 \pm 0.00$ & $0.87 \pm 0.02$ & $1.00 \pm 0.01$ \\
\hline $\begin{array}{l}\text { *Pregnant rat mammary gland } \\
(\text { Day 20) }\end{array}$ & 4 & $2.05 \pm 0.03$ & $2.09 \pm 0.04$ & $3 \cdot 60 \pm 0 \cdot 14$ & $6 \cdot 12 \pm 0 \cdot 86$ \\
\hline $\begin{array}{l}\text { *Pregnant rat mammary gland } \\
\quad(\text { Day } 20)\end{array}$ & 22 & $3.72 \pm 0.76$ & $5.07 \pm 0.05$ & $17.77 \pm 0.98$ & $17 \cdot 09 \pm 0 \cdot 88$ \\
\hline †Guinea-pig cervix & 22 & $1.93 \pm 0.01$ & $7.55 \pm 0.23$ & $14 \cdot 20 \pm 0 \cdot 67$ & $13.00 \pm 0.44$ \\
\hline †Guinea-pig pubic symphysis & 4 & $2.85 \pm 0.16$ & $3.26 \pm 0.20$ & $3.61 \pm 0.08$ & $4 \cdot 15 \pm 0.56$ \\
\hline †Guinea-pig pubic symphysis & 22 & $6.94 \pm 0.48$ & $7 \cdot 29 \pm 0 \cdot 36$ & $16 \cdot 30 \pm 1 \cdot 76$ & $16.01 \pm 1.01$ \\
\hline
\end{tabular}

Values are means \pm s.e.m. of duplicate determinations.

* A $100000 \mathrm{~g}$ fraction was prepared as described in 'Materials and Methods.' Binding material was equivalent to $485 \mu \mathrm{g}$ protein/tube.

+ Homogenates were prepared from tissues of 2 normal, virgin guinea-pigs in $0.3 \mathrm{M}$-sucrose $(1: 4 \mathrm{w} / \mathrm{v})$, filtered, and then centrifuged at $700 \mathrm{~g}$. The precipitate was resuspended in an equal volume of Tris $-\mathrm{MgSO}_{4}$ buffer (25 mMTris- $\left.\mathrm{HCl}, 5 \mathrm{~mm}-\mathrm{MgSO}_{4}, \mathrm{pH} 7 \cdot 5\right)$. An aliquot $(200 \mu \mathrm{l})$ was determined to be equivalent to $1 \cdot 2 \mathrm{mg}$ protein. Binding conditions and procedure were described in 'Materials and Methods' for mammary gland preparations.

\section{Discussion}

In the present study we have shown that those target tissues used for the biological assay and expression of relaxin in vivo also demonstrate binding of ${ }^{125} \mathrm{I}$-labelled relaxin in vitro.

The relaxin preparation used $\left(\mathrm{CM}-\mathrm{a}^{\prime}\right)$ probably contained a mixture of labelled and unlabelled material. However, we have shown that succinylated relaxin has full biological potency. The specific activities of the labelled relaxin used were low by comparison with those in other studies, for example of insulin, a hormone of similar size and structure (Podskalny, Chou \& Rechler, 1973). The low specific activity would tend to minimize any damage to the relaxin molecule. It would cause a significant amount of unlabelled relaxin to be present in the preparation used for the binding studies, thereby reducing the maximum binding of the labelled peptide. In spite of this, the maximum binding is well within the range reported for other hormones and their target cells (Gavin, Roth, Jen \& Freychet, 1972).

The present results show that mouse pubic symphysial homogenates bind ${ }^{125}$ I-labelled relaxin according to the accepted criteria for defining peptide hormone receptors: specificity, time and temperature dependency, equilibrium analysis, and target organ specificity (Ryan \& Lee, 1976). Spleen, liver and heart are not target tissues for relaxin in vivo and none of these organs bound the 
labelled relaxin in vitro. Moreover, none of the other hormones tested competed with ${ }^{125}$ I-labelled relaxin binding and unlabelled relaxin inhibited the binding of labelled relaxin. Calculations based on Text-fig. 2 show that half-maximal binding is approximately $10 \mathrm{ng} / \mathrm{ml}$. From a mol. wt of 6500 for relaxin, this gives an affinity constant $\left(K_{a}\right)$ of $10^{-9} \mathrm{M}$ which compares with those for other hormones, eg. LH, $K_{a}=10^{-11}$ to $10^{-9} \mathrm{M}$ (Ryan \& Lee, 1976), and insulin which has a $K_{a}$ value of $10^{-10} \mathrm{M}$ (Hollenberg \& Cuatrecasas, 1975).

Oestrogen priming has been shown to be necessary before relaxin will exert a maximal effect on the pubic symphysis or other tissues in vivo (Hall, 1960). It is uncertain why oestrogen priming of the mice in the present study had no effect on relaxin binding to symphysial homogenates in vitro. The timing of the oestrogen treatment may be critical and a maximal effect on the numbers of receptors might have occurred earlier than the time of death of the animals, a possibility substantiated by the observation that tissue receptors undergo modulation (Posner, Kelly, Shiu \& Friesen, 1974).

The mechanism of action of relaxin in the mouse interpubic ligament bioassay and the rat or mouse uterine relaxing factor assay is remarkably different. Although in the former the relaxin in vivo requires $12-24 \mathrm{~h}$ for maximal effect, in the latter the effect in vitro upon the oestrogen-dominated uterus occurs within minutes. It may be that relaxin, like oxytocin, has specific myometrial receptors (Soloff \& Swartz, 1974). Although the effect of oxytocin on relaxin binding was not evaluated it is unlikely they share a common binding site since the relaxin-dominated uterus will respond to oxytocin (Sawyer, Frieden \& Martin, 1953). The absence of ${ }^{125} \mathrm{I}$-labelled relaxin binding to uterine homogenates compared to the observed binding with uterine segments is difficult to explain. Unlike the mouse pubic symphysial homogenates, the uterine homogenates were not exposed to collagenase, and this could be a necessary step for uncovering relaxin receptor sites. It is also possible that the method of homogenization employed was too vigorous and destroyed the receptors.

The rat ovary synthesizes relaxin from Day 17 of pregnancy to term (Anderson, Lang \& Hayashida, 1975), and plasma relaxin levels are maximal on Day 20 of pregnancy (O'Byrne \& Steinetz, 1976). Our results with the mammary gland preparations indicate that the receptors in the developing mammary tissue are undetectable before the secretion of endogenous relaxin. Relaxin may induce the formation of its own receptors, as has been shown for prolactin (Posner, 1976) and growth hormone (Lesniak \& Roth, 1976).

The preliminary observation that an homogenate of the guinea pig pubic symphysis binds ${ }^{125} \mathrm{I}-$ labelled relaxin is not surprising in view of the fact that the symphysial response in this species has long been used as a bioassay for relaxin (Hall, 1960). Oestrogen priming was not necessary, and accords with the report that relaxin will inhibit myometrial contractions in the nonpregnant guinea-pig which has not been treated with oestrogen (Porter, 1971). The binding of the iodinated relaxin to an homogenate of guinea-pig cervix was not expected, although relaxin is known to affect the cervix in other species (Hall, 1960). Binding of a hormone to a tissue does not necessarily indicate a biological response, but it seems likely that relaxin might affect the tensile strength of the guinea-pig cervix as in other animals.

The present experiments with tissue homogenates, membrane fractions and tissue segments have shown that the various biological effects of relaxin are mediated via specific receptors for the hormone.

We thank Dr Walter Morishige, University of Hawaii, for his interest in this work which was supported by a grant from NIH, HD-06633. G.D.B-G. was a recipient of a Research Career Development Award HD-70516 and S.M.K. was supported by an Hawaii Division American Cancer Society Fellowship.

\section{References}

Anderson, M.L., LANG, J.A. \& Hayashida, T. (1975) Immunofluorescence studies on the localization of relaxin in the corpus luteum of the pregnant rat. Biol. Reprod. 13, 499-504.
Berson, S.A., Yalow, R.S., BaumanN, A., RothsCHILD, M.A. \& NeWerly, K. (1956) Insulin I-131 metabolism in human subjects: demonstration of insulin binding globulin in the circulation 
of insulin treated subjects. J. clin. Invest. 35, $170-190$.

BuIss, C.I. (1952) The Statistics of Bioassay. Academic Press, New York.

Bolton, A.E. \& Hunter, W.M. (1973) The labelling of proteins to high specific radioactivities by conjugation to a I-125 containing acylating agent. Biochem. J. 133, 529-539.

Catt, K.J., Dufau, M.L. \& Tsuruhara, T. (1972) Radioligand-receptor assay of luteinizing hormone and chorionic gonadotropin. J. clin. Endocr. Metab. 34, 123-132.

Cuatrecasas, P. (1971) Insulin-receptor interactions in adipose tissue cells : direct measurement and properties. Proc. natn. Acad. Sci. U.S.A. 68, 1264-1268.

Gavin, J.R., Roth, J., Jen, O. \& Freychet, P. (1972) Insulin receptors in human circulating cells and fibroblasts. Proc. natn. Acad. Sci. U.S.A. 69, 747-751.

HALL, K. (1960) Relaxin. J. Reprod. Fert. 1, 368-384.

Harness, J.R. \& Anderson, R.R. (1975) Effect of relaxin on mammary gland growth and lactation in the rat. Proc. Soc. exp. Biol. Med. 148, 933-936.

HollenberG, M.D. \& Cuatrecasas, P. (1975) Insulin: interaction with membrane receptors and relationship to cyclic purine nucleotides and cell growth. Fedn Proc. Fedn Am. Socs exp. Biol. 34, 1556-1563.

Kammerman, S., Canfield, R.E., Kolera, J. \& ChanNING, C.P. (1972) The binding of iodinated HCG to porcine granulosa cells. Endocrinology 91, 65-74.

Lefkowitz, R.J., Roth, J., Pricer, W. \& Pastan, I. (1970) ACTH receptors in the adrenal: specific binding of ACTH I-125 and its relation to adenyI cyclase. Proc. natn. Acad. Sci. U.S.A. 65, 745-752.

LesNiAK, M.A. \& Roth, J. (1976) Regulation of receptor concentration by homologous hormone. Effect of human growth hormone on its receptor in IM-9 lymphocytes. J. biol. Chem. 251, 3720-3729.

Lowry, O.H., Rosebrough, N.J., FARR, A.L. \& RANDALL, R.J. (1951) Protein measurement with the folin phenol reagent. J. biol. Chem. 193, 265-275.

O'Byrne, E.M. \& Steinetz, B.G. (1976) Radioimmunoassay (RIA) of relaxin in sera of various species using an antiserum to porcine relaxin. Proc. Soc. exp. Biol. Med. 152, 272-276.

O'Keefe, E.M., Hollenberg, M.D. \& Cuatrecasas, P. (1974) Epidermal growth factor: characteristics of specific binding in membranes from liver, placen- ta, and other target tissues. Archs Biochem. Biophys. 164, 518-526.

Podskalny, J.M., Chou, J.Y. \& Rechler, M.W. (1973) Insulin receptors in a new human placenta cell line: demonstration of negative cooperativity. Archs Biochem. Biophys. 170, 504-513.

PORTER, D.G. (1971) The action of relaxin on myometrial activity in the guinea pig in vivo. J. Reprod. Fert. 26, 251-253.

Posner, B.I. (1976) Regulation of lactogen specific binding sites in rat liver: studies on the role of lactogens and estrogen. Endocrinology 99, 1168-1177.

Posner, B.I., Kelly, P.A., Shiu, R.P.C. \& Friesen, H.G. (1974) Studies of insulin, growth hormone and prolactin binding: tissue distribution, species variation and characterization. Endocrinology 95, $521-531$.

RYAN, R.J. \& LEE, C.Y. (1976) The role of membrane bound receptors. Biol. Reprod. 14, 16-29.

SaVAGE, C.R. \& CohEN, S. (1972) Epidermal growth factor and a new derivative. Rapid isolation procedures and biological and chemical characterization. J. biol. Chem. 247, 7609-7611.

Sawyer, W.H., Frieden, E.H. \& Martin, A.S. (1953) In vitro inhibition of spontaneous contractions of rat uterus by relaxin-containing extracts of sow ovaries. Am. J. Physiol. 172, 547-552.

Sherwood, O.D. \& O'Byrne, E.M. (1974) Purification and characterization of porcine relaxin. Archs Biochem. Biophys. 160, 185-196.

Shiv, R.P.C., Kelly, P.A. \& Friesen, H.G. (1973) Radioreceptor assay for prolactin and other lactogenic hormones. Science, N.Y. 180, 968-971.

SolofF, M.S. \& SWARTz, T.L. (1974) Characterization of a proposed oxytocin receptor in the uterus of the rat and sow. J. biol. Chem. 249, 1376-1381.

Steel, R.D.G. \& TorRIE, J.H. (1960) Principles and Procedures of Statistics. McGraw-Hill, New York.

Steinetz, B.G., Beach, V.L., Kroc, R.L., Stasil.li, N.R., Nussbaum, R.E., Nemith, R.J. \& DuN, R.K. (1960) Bioassay of relaxin using a reference standard. A simple and reliable method utilizing direct measurement of interpubic ligament formation in mice. Endocrinology 67, 102-115.

Wiquist, N. \& Paul, K.G. (1958) Inhibition of the spontaneous uterine motility in vitro as a bioassay for relaxin. Acta endocr., Copenh. 29, 135-146.

Received 13 July 1977 